\begin{tabular}{l|l} 
Jurnal Eksplorasi Akuntansi & $\begin{array}{l}\text { ISSN : 2656-3649 (Online) } \\
\text { hol. 1, No 3, Seri F, Agustus 2019, Hal 1518-1529.jea.ppj.unp.ac.id/index.php/jea/issue/view/13 }\end{array}$
\end{tabular}

\title{
PENGARUH MEKANISME TATA KELOLA PERUSAHAAN TERHADAP PENGUNGKAPAN ISLAMIC FINANCIAL SOCIAL REPORTING (IFSR) PADA BANK SYARIAH DI INDONESIA (Studi Pada Bank Umum Syariah Di Indonesia Periode 2014-2018)
}

\author{
Maulidya Wulandari ${ }^{1}$, Vanica Serly ${ }^{2}$ \\ 1)Alumni Jurusan Akuntansi Fakultas Ekonomi,Universitas Negeri Padang \\ 2)Jurusan Akuntansi Fakultas Ekonomi, Universitas Negeri Padang \\ *Korespondensi: maulidyawulandari49@ gmail.com
}

\begin{abstract}
This study was conducted to determine the effect of independent commissioners and directors on the disclosure of Islamic Financial Reporting (IFSR). Research on Islamic Financial Social Reporting (IFSR) can be said is a fairly recent research finding from a copy of research on ISR, GCG, and financial disclosure. For research in Indonesia, no research has been found that addresses the disclosure of IFSR in Islamic Banks. The IFSR is an index that covers all aspects of financial disclosure, governance, and Islamic social responsibility. The population of this study is Islamic banking in Indonesia, amounting to 12 banks which published annual reports from 2014-2018. Data collection method in this research is documentation study. Analysis of the data used is descriptive statistics, classic assumption tests, and for hypotheses using multiple linear regression analysis. The results of this study indicate that the number of independent commissioners and the number of directors has a positive effect on the disclosure of Islamic Financial Social Reporting (IFSR).
\end{abstract}

Keywords: disclosure; tata kelola, bank syariah, islamic financial social reporting (IFSR)

How to cite (APA $6^{\text {th }}$ style)

Wulandari, M., \& Serly, V. (2019). Pengaruh Mekanisme Tata Kelola Perusahaan terhadap Pengungkapan Islamic Financial Social Reporting (IFSR) pada Bank Syariah di Indonesia (Studi pada Bank Umum Syariah di Indonesia Periode 2014-2018). Jurnal Eksplorasi Akuntansi, 1(3), Seri F, 1518-1529.

\section{PENDAHULUAN}

Perbankan di Indonesia kini makin diramaikan dengan adanya bank syariah, yang menawarkan produk keuangan dan investasi dengan cara yang berbeda dibanding bank konvensional yang sudah lama ada. Peraturan tentang bank syariah bahwa perbankan syariah dalam melakukan kegiatan usahanya berasaskan prinsip syariah, demokrasi ekonomi, dan prinsip kehati-hatian.

Seiring dengan perkembangan bank syariah yang terus meningkat, satu hal perlu dicermati adalah aspek Good Coorporate Governance (GCG) yang merupakan unsur penting di industri perbankan syariah. Hal ini berkaitan dengan risiko dan tantangan yang dihadapi oleh industri perbankan syariah yang semakin meningkat. Penilaian terhadap GCG sebagaimana juga 
diatur dalam Undang-Undang Otoritas Jasa Keuangan dalam Pasal 6 ayat (1) huruf b merupakan penilaian terhadap manajemen bank umum syariah atas pelaksanaan prinsip-prinsip GCG.

Untuk penerapan GCG yang efektif di lembaga perbankan syariah, maka Bank Indonesia mengeluarkan peraturan, yaitu Peraturan Bank Indonesia (PBI) Nomor 11/33/PBI/2009 tanggal 7 Desember 2009 tentang pelaksanaan Good Corporate Governance bagi bank umum syariah dan unit usaha syariah. PBI ini sudah berlaku sejak 1 Januari 2010. PBI GCG bank syariah mengatur penerapan GCG bagi dewan komisaris yang memiliki tugas melakukan kontroling dan memberikan masukan kepada pihak direksiyang merupakan organ penting yang berwenang dan bertanggung jawab penuh atas pengurusan untuk kepentingan bank.

Persektif teori agensi merupakan dasar yang digunakan memahami tata kelola bank syariah. Teori agensi yakni hubungan antara manajemen dengan pemilik, manajemen sebagai agen secara moral bertanggung jawab untuk mengoptimalkan keuntungan para pemilik (principal) dan sebagai imbalannya akan memperoleh kompensasi yang sesuai dengan kontrak. Teori agensi dalam perspektif Islam yaitu agen sebagai pihak yang diberi amanah untuk menjalankan dana dari pihak pemilik (principal) harus mempertanggungjawabkan apa yang sudah di amanahkan. Di lain pihak prinsipal sebagai pihak pemberi amanah memberikan insentif kepada agen berbagai macam fasilitas baik finansial maupun nonfinansial. Permasalahan dapat timbul ketika kedua belah pihak mempunyai persepsi dan sikap yang berbeda dalam hal pemberian informasi yang akan digunakan oleh prinsipal untuk memberikan insentif kepada agen.

Pengelolaan perbankan syariah serta peran dan fungsi manajemen menentukan kinerja suatu bank dalam menghasilkan keuntungan.Sehingga perkembangan kegiatan operasional bank syariah tergantung pada pengelolaan manajemen keuangan yang baik serta peran penting organ perbankan yakni dewan direksi dan dewan komisaris. Dewan direksi berkewajiban mengelola perbankan syariah sesuai dengan wewenang dan tanggungjawabnya sebagaimana dalam anggaran dasarnya dan sesuai dengan peraturan perundang-undangan yang sudah berlaku. Sedangkan dewan komisaris berkewajiban memastikan bahwa direksi melakukan tindak lanjut hasil temuan audit dan rekomendasi satuan kerja atau pejabat yang bertanggungjawab terhadap pelaksanaan audit internal, eksternal, hasil pengawasan dewan komisaris, OJK dan pihak otoritas lainnya

Dalam penelitian Islamic Financial Social Reporting(IFSR) dapat dikatakan adalah temuan penelitian yang cukup baru dari tembusan penelitian mengenai ISR, GCG, dan pengungkapan keuangan. Perluasan ini merupakan penambahan IFSR indeks yang terkandung pada penelitian sebelumnya. Penelitian ini merupakan replikasi dari penelitian tentang perbankan syariah yang dilakukan oleh Marsidi (2016) mengenai IFSR di Bank Malaysia.

Tujuan penelitian ini adalah untuk menganalisis pengaruh tata kelola terhadap pengungkapan Islamic Financial Social Reporting (IFSR) pada Bank umum syariah di Indonesia. Dari hasil penelitian diharapkan dapat memberikan manfaat bagi banyak pihak dan juga menambah literatur serta dapat bermanfaat bagi pemerintah sebagai bahan pertimbangan pemerintah dan lembaga regulator lainnya dalam meningkatkan kualitas standar peraturan dalam pengungkapan IFSR.

\section{REVIU LITERATUR DAN HIPOTESIS}

Teori keagenan adalah dasar yang digunakan untuk memahami konsep Good Corporate Governance. Teori agensi ini adalah sebuah kontrak antara manajer (agent) dengan pemilik (principal). Agar hubungan kontraktual ini dapat berjalan dengan lancar, pemilik akan 
mendelegasikan otoritas pembuatan keputusan kepada manajer. Hubungan keagenan adalah suatu kontrak dimana satu atau beberapa orang (pemberi kerja atau principal) memperkerjakan orang lain (agen) untuk melaksanakan sejumlah jasa mendelegasikan wewenang untuk mengambil keputusan kepada agen.

Dalam konsep Islam dikatakan sebuah kejelasan tentang hubungan yang terkait dengan suatu bentuk kerjasama antara manajer (agent) dan pemilik (principal). Nilai mutlak yang muncul pada hubungan antara pengamanah dan yang menerima amanah adalah semata atas kuasa-Nya. Apabila ada sebuah kontrak antara manajer (agent) dengan pemilik (principal), essensi yang terjadi pada kedua belah pihak bahwa mereka bersama harus melaksanakan amanah atas kepemilikan yang dipercayakan oleh Allah kepada mereka sebagai bentuk manifestasi atas fungsi manusia sebagai Khalifatullah Fill Ardh.

Bank islam atau yang biasa dikenal dengan bank syariah yaitu bank yang beroperasi dengan tidak menunggulkan pada bunga. Bank syariah adalah lembaga keuangan perbankan yang operasional dan produknya dikembangkan dilandasi oleh Al-Qur'an dan Hadist Nabi SAW. Dengan kata lain bank syariah merupakan bank yang melakukan kegiatan usaha atau beroperasi berdasarkan prinsip syariah dan tidak mengunggulkan pada bunga dalam memberikan pembiayaan dan jasa lainnya dalam lalu lintas pembayaran. Prinsip dasar perbankan syariah berdasarkan pada Alquran dan sunnah. Setelah dikaji lebih dalam falsafah dasar beroperasinya bank syariah yang menjiwai seluruh hubungan transaksinya berprinsip pada tiga hal yaitu efisiensi, keadilan, dan kebersamaan.

Tata kelola atau biasa disebut dengan GCG (Good Corporate Governance) adalah suatu sistem yang dianut oleh perusahaan untuk mengimplementasikan suatu sistem pengelolaan yang baik dalam perusahaan. Terdapat banyak definisi yang muncul mengenai GCG dari berbagai ahli, namun pada dasarnya makna dari Good Corporate Governance dari berbagai definisi ialah tata kelola perusahaan suatu sistem yang dirancang untuk membuat kinerja dan opera.

Dewan komisaris independen merupakan anggota dewan komisaris yang tidak memiliki hubungan keuangan, hubungan kepengurusan, hubungan kepemilikan saham, ataupun hubungan keluarga lainnya dengan para anggota dewan komisaris lainnya, direksi dan pemegang saham pengendali atau hubungan dengan bank, yang dapat mempengaruhi kemampuannya untuk bertindak secara independensional perusahaan menjadi lebih terarah berdasarkan prinsip-prinsip yang ada dalam GCG.

Dewan direksi yakni seseorang yang memegang seluruh pertanggungjawaban perusahaan/bank bisa dikatakan merupakan orang profesional yang ditunjuk oleh pemilik perusahaan/bank untuk menjalankan dan memimpin perusahaan. Sebutan untuk dewan direksi dapat berupa dewan manager, dewan gubernur, atau dewan eksekutif. Salah satu bentuk akuntabilitas dalam perspektif ekonomi Islam yakni pelaporan tanggung jawab sosial perusahaan yang sesuai dengan prinsip syariah. Sehingga IFSR (Islamic Financial Social Reporting) dapat diartikan sebagai standar pelaporan kinerja sosial perusahaan yang berbasis syariah baru yang sebelumnya dikenal dengan ISR (Islamic Social Reporting). IFSR merupakan perluasan dari indeks ISFR yang menjadi tolak ukur pelaksanakaan tanggung jawab sosial perbankan syariah yang dikembangkan dengan dasar dari standar pelaporan berdasarkan AAOIFI yang kemudian dikembangkan oleh peneliti-peneliti berikutnya. 
Pengaruh Ukuran Dewan Komisaris Independen terhadap Pengungkapan Keuangan, Tata Kelola, dan Tanggung jawab sosial islam bank syariah di Indonesia

Dewan komisaris independen merupakan sebuah badan dalam perusahaan yang beranggotakan dewan komisaris independen yang berasal dari luar perusahaan yang berfungsi untuk menilai kinerja perusahaan secara luas dan keseluruhan. Semakin besar persentase anggota luar perusahaan (komisaris independen) akan menjadikan peranan dewan komisaris semakin efektif dalam melaksanakan fungsi pengawasan terhadap pengelolaan perusahaan, karena dianggap semakin independen

Dewan komisaris independen diangkat melalui Rapat Umum Pemegang Saham (RUPS). Proporsi dewan komisaris yang ada dalam suatu perusahaan berpengaruh terhadap fungsi pengawasan pada pengambilan kebijakan dalam perusahaan. Pengawasan ini termasuk dalam kaitannya terhadap sikap stakeholder dalam menangani risiko yang ada di bank.

H1: Ukuran dewan komisaris independen berpengaruh positif terhadap pengungkapan Islamic Financial Social Reporting pada perbankan syariah di Indonesia

\section{Pengaruh Dewan Direksi terhadap Pengungkapan keuangan, Tata Kelola, dan Tanggung} Jawab Social Islam pada Bank Syariah di Indonesia

Direksi diketuai oleh presiden direktur yang tugasnya bertanggung jawab atas pelaksanaan fungsi kepengurusan bank secara efektif dan efesien. Presiden direktur diwajibkan untuk membuat direksi sebagai lembaga kolegial yang mampun bekerja secara transparan dan masingmasing anggota dapat berperan sebagai anggota tim maupun dalam fungsinya masing-masing sesuai dengan bidang tugas yang disepakati.

Dewan direksi yakni pelaku yang bertanggung jawab atas seluruh fungsi manajerial, yang meliputi pengembangan dan eksekusi strategi korporasi, pengamanan sumber daya, penilaian kinerja finansial, penyajian laporan keuangan yang wajar, dan peningkatan nilai jangka panjang.

H2: Ukuran dewan direksi berpengaruh positif terhadap pengungkapan Islamic Financial Social Reporting pada Perbankan Syariah di Indonesia

\section{METODE PENELITIAN}

Penelitian ini merupakan penelitian kuantitatif dimana jenis penelitian kuantitatif menjelaskan tentang fakta-fakta dari objek yang diteliti dengan menganalisis data angka menggunakan metode statistik melalui pengujian hipotesis. Data yang digunakan adalah data sekunder/sumber sekunder. Penelitian ini menggunakan content analysis dalam menilai Islamic Financial Social Reporting (IFSR) bank syariah dengan unit analisis laporan tahunan bank syariag. Content analysis yaitu metode penelitian observasi yang digunakan untuk mengevaluasi secara secara sistematis isi dari suatu informasi. Populasi dalam penelitian ini adalah semua bank umum syariah di Indonesia yang berjumlah 12 unit bank yakni :

\begin{tabular}{|l|l|}
\hline No & Nama Bank \\
\hline 1 & Bank Syariah Bukopin \\
\hline 2 & Bank Mega Syariah \\
\hline 3 & Bank Muamalat Indonesia \\
\hline 4 & Bank Syariah Mandiri \\
\hline 5 & Bank Central Asia Syariah \\
\hline 6 & Bank Negara Indonesia Syariah \\
\hline
\end{tabular}




\begin{tabular}{|l|l|}
7 & Bank Rakyat Indonesia Syariah \\
\hline 8 & Panin Bank Syariah \\
\hline 9 & Bank Jabar Banten Syariah \\
\hline 10 & Bank Maybank Syariah Indonesia \\
\hline 11 & Bank Victoria Syariah \\
\hline 12 & Bank Tabungan Pensiun Nasional Syariah \\
\hline
\end{tabular}

Unit analisis yang dipakai dalam penelitian ini yaitu laporan tahunan bank umum syariah.Periode penelitian ini adalah tahun 2014-2018. Penentuan sampel yang digunakan dengan teknik purposive sampling, yaitu pemilihan data yang akan digunakan sesuai kriteriakriteria tertentu. Variabel bebas pada penelitin ini adalah dewan komisaris independen yang merupakan anggota dewan komisaris yang tidak terafiliasi dengan direksi, anggota dewan komisaris lainnya dan pemegang saham pengendali, serta bebas dari hubungan bisnis atau hubungan lainnya yang dapat mempengaruhi kemampuannya untuk bertindak independen atau bertindak semata-mata demi kepentingan perusahaan. Dan variabel bebas kedua adalah dewan direksi yag merupakan organ perseroan yang berwenang dan bertanggung jawab penuh atas pengurusan perseroan untuk kepentingan perseroan, sesuai dengan maksud dan tujuan perseroan serta mewakili perseroan, baik di dalam maupun di luar pengadilan sesuai dengan ketentuan anggaran dasar.

Variabel dependen pada penelitian ini adalah Islamic Financial Social Reporting (IFSR). Variabel ini diukur dengan indeks IFSR dari masing-masing perusahaan setiap tahunnya. Nilai indeks diperoleh dengan menggunakan content analysis method (metode konten analisis). Dalam penelitian ini, jumalah item yang digunakan untuk mengukur indeks IFSR yaitu dapat dilihat pada tabel berikut:

\begin{tabular}{|r|l|}
\hline NO & \multicolumn{1}{|c|}{ Indikator } \\
\hline & Pengungapan Keuangan \\
\hline & Laporan mencakup informasi berikut ini : \\
\hline 1 & Ikhtisar kinerja \\
\hline 2 & Pernyataan tata kelola \\
\hline 3 & Laporan direksi \\
\hline 4 & Pernyataan direksi \\
\hline & $\begin{array}{l}\text { Deklarasi hukum oleh direksi atau orang yang bertanggung jawab } \\
\text { menyusun laporan keuangan bank islam }\end{array}$ \\
\hline 6 & Laporan auditor \\
\hline 7 & Laporan dewan pengawas syariah \\
\hline & Laporan keuangan haruslah mencakup informasi sebagai berikut : \\
\hline 8 & Laporan posisi keuangan \\
\hline 9 & Laporan laba rugi \\
\hline 10 & Laporan perubahan ekuitas \\
\hline 11 & Laporan arus kas \\
\hline
\end{tabular}




\begin{tabular}{|r|l|}
12 & Catatan atas laporan keuangan \\
\hline & Laporan posisi keuangan harus mengungkapkan informasi berikut \\
\hline 13 & Aset \\
\hline 14 & Liabilitas \\
\hline 15 & Ekuitas \\
\hline 16 & $\begin{array}{l}\text { Aset, liabilitas, ekuitas diungkapkan secara terpisah pada catatan } \\
\text { atas laporan keuangan }\end{array}$ \\
\hline & Analisis pendapatan dilaporkan berdasarkan tipe investasi dan \\
17 & keuangan konsumen. \\
\hline & Penyajian dividen diakui : \\
\hline 18 & Diungkapkan melalui lpe atau calk \\
\hline 19 & Jumlah yang didistribusikan kepemilik selama periode \\
\hline 20 & Berkaitan dengan jumlah per lembar saham \\
\hline & Kewajiban zakat \\
\hline 21 & Metode \\
\hline 22 & Jumlah dan penerima zakat \\
\hline 23 & Pembayaran atas nama deposan, pemegang saham, dll. \\
\hline 24 & Kebijakan atas denda dan klien pailit/beban piutang tak tertagih \\
\hline & Pengungkapan pendapatan atau beban yang dilarang oleh syariah \\
\hline 25 & Pendapatan yang direalisasi \\
\hline 26 & Sifat pendapatan yang direalisasi \\
\hline 27 & Jumlah beban \\
\hline 28 & Sifat beban \\
\hline 29 & Perlakuan terhadap pendapatan tidak halal yang dihapuskan \\
\hline & Laporan produk atau jasa \\
\hline 30 & Aktivitas dan persentase kontribusi laba \\
\hline & Pelaporan resiko aset di beberapa area berikut : \\
\hline 31 & Area geografis \\
\hline 32 & Kelompok konsumen \\
\hline 33 & Sektor industry \\
\hline 34 & Konsentrasi resiko lainnya yang dianggap tepat \\
\hline 36 & Dasar alokasi laba antara ekuitas pemilik dan akun pemegang \\
investasi \\
\hline 36 & $\begin{array}{l}\text { Pelaporan konsentrasi sumber akun investasi dan setaranya dan } \\
\text { akun lainnya. }\end{array}$ \\
\hline & Pengungkapan akun distribusi investasi dan setaranya dan akun \\
\hline & lainnya sesuai dengan periode jatuh tempo masing-masing \\
\hline & periode yang diharapkan untuk di konversi menjadi kas \\
\hline & \\
\hline
\end{tabular}




\begin{tabular}{|r|l|} 
& Pengungkapan komitmen dan kontijensi \\
\hline 39 & Sifat komitmen yang tidak dapat diperbaiki \\
\hline 40 & Jumlah komitmen yang tidak dapat diperbaiki \\
\hline & $\begin{array}{l}\text { Sifat kontinjensi yang timbul dari kredit langsung pengganti, } \\
\text { transaksi terkait kontinjensi, penjualan dan janji dibeli kembali, dan } \\
\text { kontinjensi lainnya yang sifatnya serupa }\end{array}$ \\
\hline & $\begin{array}{l}\text { Jumlah kontinjensi yang timbul dari kredit langsung pengganti, } \\
\text { transaksi terkait kontinjensi, penjualan dan janji dibeli kembali, dan } \\
\text { kontinjensi lainnya yang sifatnya serupa. }\end{array}$ \\
\hline 42 & Pelaporan kategori deposit ke pendanaan tunggal \\
\hline 43 & Metode alokasi pendapatan terhadap berbagai kategori deposit \\
\hline & $\begin{array}{l}\text { Pengungkapan distribusi laba yang diperoleh dari investasi dana } \\
\text { deposan di tingkat bruto }\end{array}$ \\
\hline 44 & $\begin{array}{l}\text { Setelah dikurangi pengeluaran yang diatribusikan secara langsung } \\
\text { dengan investasi dana tersebut. }\end{array}$ \\
\hline & Pelaporan rekening investasi khusus \\
\hline 45 & Pengungkapan terpisah laba atau rugi \\
\hline 46 & Tidak diimbangi dengan keuntungan atau kerugian dari item \\
\hline & lainnya \\
\hline 47 & Informasi tentang akun investasi \\
\hline 48 & Metode perhitungan laba \\
\hline 49 & Alokasi aset \\
\hline 50 & Strategi investasi \\
\hline 51 & Mekanisme pemeratan laba (return) \\
\hline 52 & $\begin{array}{l}\text { Informasi tentang setiap transaksi dengan pihak istimewa dan } \\
\text { perlakuan peristiwa material. }\end{array}$ \\
\hline & Karyawan Masyarakat Lingkungan \\
\hline 53 & Pendidikan dan pelatihan / pengembangan karyawan. \\
\hline 54 & Kebijakan rekrutmen \\
\hline 55 & Kebijakan remunerasi. \\
\hline 56 & Kebijakan promosi karir. \\
\hline 57 & Kebijakan pension \\
\hline 58 & Amal / hadiah. \\
\hline 59 & Kegiatan sosial \\
\hline 60 & Kebijakan tentang isu-isu sosial. \\
\hline 61 & Kebijakan tentang isu-isu lingkungan. \\
\hline 62 & Sedekah/ sumbangan \\
\hline & Tata kelola dan audit \\
\hline & Pernyataan tata kelola perusahaan harus mencakup sebagai berikut : \\
\hline
\end{tabular}




\begin{tabular}{|r|l|}
63 & Tanggung jawab dewan dan pengawasan \\
\hline 64 & Audit internal dan kegiatan pengendalian internal \\
\hline 65 & Manajemen risiko \\
\hline 66 & $\begin{array}{l}\text { Laporan manajemen } \\
\text { menetapkan: }\end{array}$ \\
\hline & $\begin{array}{l}\text { Peran dan fungsi masing-masing organ pemerintahan strategis dan } \\
\text { mekanisme menyeimbangkan akuntabilitas mereka ke berbagai } \\
\text { pemangku kepentingan }\end{array}$ \\
\hline 67 & $\begin{array}{l}\text { Peran dan kewenangan syariah penasihat untuk memantau kegiatan } \\
\text { yang berkaitan dengan masalah syariah }\end{array}$ \\
\hline & $\begin{array}{l}\text { Pemegang akun investasi untuk memantau kinerja investasi, yaitu } \\
\text { pengungkapan kebijakan dan praktik sehubungan dengan rekening } \\
\text { investasi yang ditawarkan. }\end{array}$ \\
\hline 70 & $\begin{array}{l}\text { Pengungkapan praktik, prosedur dan hak yang memadai untuk } \\
\text { mengatasi setiap ambiguitas yang tidak diinginkan yang berkaitan } \\
\text { dengan gharar sehubungan dengan cadangan pemerataan laba }\end{array}$ \\
\hline 71 & $\begin{array}{l}\text { Pengungkapan mekanisme yang tepat untuk memperoleh putusan } \\
\text { dari syariah ulama, menerapkan fatwa dan pemenuhan syariah. }\end{array}$ \\
\hline 71 & $\begin{array}{l}\text { Informasi tentang kepatuhan dengan aturan syariah aturan dan } \\
\text { prinsip-prinsip sebagaimana dinyatakan dalam putusan dari dewan } \\
\text { pengawas syariah }\end{array}$ \\
\hline 73 & $\begin{array}{l}\text { Pelaporan keputusan dari dewan pengawas syariah yang digunakan } \\
\text { untuk memeriksa kepatuhan aturan dan prinsip-prinsip syariah }\end{array}$ \\
\hline 74 & Kebijakan perlakuan untuk kegiatan yang tidak mematuhi aturan. \\
\hline
\end{tabular}

\section{METODE ANALISIS DATA}

\section{Analisis statistik deskriptif}

Statistik yang digunakan untuk menganalisis data dengan cara mendeskripsikan atau menggambarkan data yang telah terkumpul sebagaimana adanya tanpa bermaksud membuat kesimpulan yang berlaku untuk umum atau generalisasi. Dalam statistik deskriptif antara lain adalah penyajian data melalui tabel, grafik, diagram lingkaran, pictogram, perhitungan modus, median, mean (pengukuran tendesi sentral), perhitungan desil, persentil, perhitungan penyebaran data melalui perhitungan rata-rata dan standar deviasi, perhitungan persentase.

\section{Uji Asumsi Klasik}

Dilakukan untuk mengetahui kelayakan dari suatu model regresi. Sebelum melakukan analisis regresi dilakukan uji asumsi klasik terlebih dahulu. Dalam penelitian ini, uji asumsi klasik yang digunakan antara lain: 
a) Uji Normalitas

Bertujuan untuk menguji apakah sampel yang digunakan memiliki distribusi normal atau tidak. Dalam model regresi linier, asumsi ini ditujukan oleh nilai error yang berdistribusi normal. Model regresi yang baik yaitu model regresi yang dimiliki distribusi normal atau mendekati normal, sehingga layak dilakukan pengujian secara statistik. Pengujian normalitas data menggunakan Test of Normality Kolmogorov-Smirnov dalam program SPSS.

b) Uji Multikolinieritas

Uji Multikolinieritas merupakan suatu situasi dimana beberapa atau semua variabel bebas berkorelasi kuat.

c) Uji Heteroskedastisitas

Heteroskedastisitas bertujuan untuk menguji apakah dalam sebuah model regresi, terjadi ketidaksamaan varians atau residual dari satu pengamatan ke pengamatan yang lain.

d) Uji Autokolerasi

Bertujuan sebagai penguji apakah dalam model regresi terdapat kolerasi antara kesalahan pengganggu pada periode-t dengan kesalahan pengganggu pada periode $t-1$ (periode sebelumnya).

\section{Analisis Regresi Linear Berganda}

Untuk mengukur analisis regresi berganda menggunakan alat bantu dengan program SPSS. Analisis linear regresi berganda bermaksud meramalkan bagaimana keadaan naik turunnya variabel dependen, bila terdapat dua atau lebih variabel independen sebagai faktor prediktor dimanipulasi (dinaik turunkan nilainya).

a) Uji koefesien determinan

Digunakan untuk mengetahui tingkat ketepatan paling baik dalam analisis regresi, hal ini ditunjukan oleh besarnya koefesien determinasi $\left(\mathrm{R}^{2}\right)$.

b) $\mathrm{Uji} F$

Uji signifikan simultan bertujuan untuk mengetahui apakah variabel bebas secara bersamasama mempengaruhi variabel terikat.

c) Uji t

Uji t digunakan untuk menunjukkan ada atau tidaknya pengaruh satu variabel bebas secara individual terhadap variabel terikat.

\section{HASIL PENELITIAN \\ Analisis statistic deskriptif}

Berdasarkan data yang diolah dapat dilihat bahwa jumlah data dari penelitian ini sebanyak 60 data observasi. Hasil uji diatas menunjukkan nilai minimum, maksimum, rata-rata (mean), dan standar deviasi untuk setiap variabel sebagai berikut Variabel Independen pertama yaitu Dewan Direksi menunjukkan jumlah dewan direksi pada masing-masing bank.

Berikut hasil dalam penelitian ini BDI memiliki nilai minimum 2,00, nilai maksimum 7,00, nilai rata-rata (mean) 3.6000 dan nilai standard deviation sebesar 0,96023. Variabel Independen kedua ialah dewan komisaris independen menunjukkan jumlah anggota dewan komisaris independen pada bank syariah. Berikut hasil dalam penelitian ini BDS memiliki nilai minimum 3,00, nilai maksimum 7,00 nilai ratarata (mean) 4.4167 dan nilai standard deviation sebesar 1.25268 Variabel Dependen Islamic Financial Social Reporting (IFSR) yang dilakukan dengan menggunakan nilai didapat dari analisis tingkat pengungkapan Islamic Financial Social 
Reporting (ISR). Berikut hasil dalam penelitian ini IFSR memiliki nilai minimum 55.00 nilai maksimum 67.00 rata-rata (mean) 61.5167 dan nilai standard deviation sebesar 3.35722.

\section{Uji Asumsi Klasik}

a. Uji normalitas

Berdasarkan hasil uji normalitas pada data yang diolah menunjukkan bahwa data penelitian telah terdistribusi secara normal yang dibuktikan dengan asymp sig. sebesar 0,289 yang lebih besar dari tingkat signifikansi penelitian 5\% atau 0,05. Oleh karena itu pada penelitian yang telah terdistribusi secara normal, maka data dapat digunakan dalam pengujian dengan model regresi berganda.

b. Uji Multikolinearitas

Berdasarkan data yang diolah diatas menunjukkan bahwa nilai VIF adalah $<10$. Nilai VIF dari BDI sebesar 1.402 ; nilai VIF dari BDS sebesar 1.402. Sedangkan nilai tolerance > 0,10 atai $<1$ dengan nilai Tolerance dari BDI sebesar 0,713; nilai tolerance dari BDS sebesar 0,713. Berdasarkan nilai VIF dan tolerance dapat disimpulkan bahwa model regresi tidak terjadi multikolinearitas. Dengan demikian pengujian selanjutnya dapat dilakukan karena telah memenuhi syarat pengujian asumsi klasik yaitu tidak terjadi multikolinearitas.

c. Uji Heteroskedastisitas

Berdasarkan data yang diolah menunjukkan bahwa p-value (sig) dalam tiap model regresi yang digunakan dalam penelitian ini lebih besar dari 0,05. Nilai Sig pada BDI sebesar 0,633; nilai Sig pada BDS sebesar 0,600. Dengan demikian dapat dinyatakan bahwa tidak terjadi gejala heterokedastisitas dalam semua model regresi penelitian ini.

d. Uji Autokolerasi

Hasil uji autokolerasi pada data yang diolah menunjukan bahwa data pada durbin watson sebesar 1.724 dimana du < $\mathrm{d}<(4-\mathrm{dl})$ yaitu du $(\mathrm{N}=60, \mathrm{~K}=3): 1,6889.4-\mathrm{du}=4-1,6889$ $=2.3111$. Jadi $1,724>1,6889,1,724<2,3111$. Berdasarkan nilai durbin watson dapat disimpulkan bahwa model regresi tidak terjadi autokolerasi.

\section{Uji hipotesis}

a. Koefesien determinasi

Dari data yang telah diolah menunjukkan besarnya nilai adjusted $R 2$ sebesar 0,263 atau 0,30\%. Hasil ini berarti ialah 26,30\% variasi pengungkapan IFSR dapat dijelaskan oleh variabel frekuensi jumlah dewan direksi (BDI) dan dewan komisaris independen (BDS) yang mana sisanya $73,70 \%$ dijelaskan oleh variable lain diluar model yang diteliti.

b. Uji f

Data penelitian yang telah diolah menunjukkan bahwa nilai signifikan pada tabel Anova mempunyai nilai 0,000 yang artinya nilai signifikan $\mathrm{F}$ pada tabel Anova $>0,05$ atau $(0,000>0,05)$ dengan hal ini menunjukkan bahwa adanya pengaruh dewan direksi dan Dewan Komisaris Independen terhadap Islamic Financial Social Reporting (IFSR).

c. Uji t

Berdasarkan data yang diolah dimana uji $\mathrm{t}$ apabila sig $<0,05$ hasil akan berpengaruh signifikan dan sig >0,05, hasil tidak berpengaruh signifikan. Hasil dari sig BDI yaitu 0,003 dan BDS 0,019 jadi dapat disimpulkan BDI dan BDS berpengaruh signifikan terhadap IFSR. 


\section{KESIMPULAN, SARAN \\ Kesimpulan}

a. Jumlah dewan komisaris independen berpengaruh positif signifikan terhadap Islamic Financial Social Reporting (IFSR). Dilihat dari hasil tersebut dewan komisaris independen yang dipandang lebih baik dengan menerapkan kebijakan yang berkaitan dengan perusahaan lebih objektif. Dewan komisaris independen dianggap mampu dalam memantau seluruh kegiatan dan juga pencegahan penipuan dalam laporan tahunan bank syariah di Indonesia.

b. Julmah dewan direksi berpengaruh positif signifikan terhadap Islamic Financial Social Reporting (IFSR). Hal ini mengidentifikasi bahwa pengungkapan yang terdapat pada laporan tahunan sangat memenuhi ketaatan laporan yang telah diatur regulator. Boleh jadi juga jumlah dewan direksi dalam hal ini selalu membahas tentang apa yang mereka pertanggungjawabkan sebagaimana tugas dari dewan direksi yang bertanggung jawab penuh atas pengurusan bank syariah untuk kepentingan bank syariah tersebut sesuai dengan maksut dan tujuan dari bank syariah. Dewan direksi pada bank-bank syariah di Indonesia telah melaksanakan fungsi kepengurusan bank syariah secara efektif dan efesien.

\section{Saran}

a. Peneliti selanjutnya, disarankan untuk menambahkan variabel independen lain seperti kepemilikan perusahaan, leverage, dan umur perusahaan yang nantinya dapat berpengaruh terhadap Islamic Financial Social Reporting (IFSR).

b. Peneliti selanjutnya, disarankan untuk menambahkan periode waktu agar mendapatkan hasil yang maksimal.

\section{DAFTAR PUSTAKA}

Abatecola, G. (2012). Organizational Adaptation: An Update. International Journal of Organizational Analysis, 20.

Annisa Stellata A.W. Analisis Kinerja Bank Umum Syariah dan Bank Umum Konvensional dengan Perspektif Balanced Scorecard. Jurnal ilmu dan Riset manajemen, Vol 4. No 6. 2015.

Anggraeni, Mariska Dewi. 2011. Agency Theory Dalam Perspektif Islam. Jurnal Hukum Islam (JHI) Volume 9, Nomor 2, Desember 2011 (272-288)

Baidok, W., \& Septiarini, D. F. (2016). Jurnal Ekonomi Syariah Teori dan Terapan, 1020-1034.

Baiman. S. Agency Research in Managerial Accounting: A Second Look. Accounting Organizations and Society. 1990. $241-371$

Bugshan, Turki, 2005, Corporate Governance, Earing Management and the Information Content of Accounting Earnings, Theoritical Model and Empirical Tests, A Dissertation, Bond University Quensland, Australia.

Darrough, M.N. (1993). "Disclosure Policy and Competition: Cournot vs

Bertrand". The Accounting Review, 68 (3), 534-561.

Effendi, Muh. Arief. 2009. The Power of Good Corporate Governance: Teori dan Implementasi. Salemba Empat: Jakarta

Evans, Thomas G, 2003, Accounting Theory: Contemporary Accounting Issues, Thomson, South Western, Australia. 
Fauzi, Fitriya dan Stuart Locke. (2012) "Board Structure, Ownership Structure and Firm Performance: A study of New Zealand Listed-Firms". Asian Academy of Management Journal of Accounting and Finance, 8 (2): 43-67

https://www.ojk.go.id/id

Marsidi A., Hairul A. A., Abdul R., The Impact of Corporate Governance on the Financial, Governance and Social Disclosure at Islamic Banks in Malaysia. Journal of Islamic Finance, Vol. 7 No. 1 (2018) 009

Ningrum, Ratna Aditya dkk. 2013. Pengaruh Kinerja Keuangan, Kepemilikan Institusional dan Ukuran Dewan Pengawas Syariah terhadap Pengungkapan Islamic Social Reporting (ISR). Accounting Analysis Journal 4.

Othman dan Thani, 2010. Islamis Social Reporting of Listed Companies in Malaysia. International Business \& Economics Research Journal Vol. 9. Pp.135-144. 